\title{
The Performance of Newly Issued Stocks in Thailand
}

\author{
Vesarach Aumeboonsuke \\ Martin de Tours School of Management of Economics \\ Assumption University, Bangkok, Thailand \\ Tel: 66-2723-2222 E-mail: vesarach@gmail.com \\ Nopphon Tangjitprom (Corresponding author) \\ Martin de Tours School of Management of Economics \\ Assumption University, Bangkok, Thailand \\ Tel: 66-8-5815-6177 E-mail: tnopphon@gmail.com
}

Received: September 16, 2011

Accepted: September 26, 2011

Published: January 1, 2012

doi:10.5539/ijef.v4n1p103

URL: http://dx.doi.org/10.5539/ijef.v4n1p103

\begin{abstract}
This paper aims to examine the relative long-run performance of the newly issued stocks in the Stock Exchange of Thailand (SET). The sample of 325 newly issued stocks in Stock Exchange of Thailand during the year 1990 - 2006 is filtered to 314 stocks by excluding the issues during the mid-1997 to 1998 Asian Financial Crisis period. 3-year and 5-year holding period returns of IPO portfolio are compared with those of the matching firms. In addition to the event study, the time series cross-sectional regressions are employed to investigate the long-run overpriced of newly issued stocks when controlling for size and Book-to-Market Value ratio. The overall results show that, relative to that of the size-matched portfolio, the long-run performance of portfolio consist of was underperformed by approximately $15 \%$ and $29 \%$ for the three-year holding period portfolio and five-year holding period portfolio, respectively.
\end{abstract}

Keywords: IPO, New issues, Stock Exchange of Thailand

\section{Introduction}

Most investors believe that they can make profit significantly from investing in newly issued stocks. Especially during the bull stock market, newly issued stocks become the main interest of most investors. This is exceptionally true for the newly issued stocks in case of the offering of well-known private firms and the privatization of large state enterprises. Normally, these IPO can perform outstandingly in short term after the first trading day. It means that investors can make abnormal profit from investing in newly issued stocks for only a few days after the first trading day.

In order to clarify the belief of people, many researchers tried to track out the performance of newly issued stocks and their comparable ones in order to show that investing in newly issued stocks can really make abnormal return. Many researches show the short term positive return from investing in newly issued stocks. They describe these undervalued stocks by the price discounts as the result of higher perceived risk and asymmetric information of newly issued stocks. Some mention that this discount or underpricing come from the fact that issuers really need to sell newly issued stocks more easily and widely. Nevertheless, surprisingly, many researches show that these newly issued stocks become overpriced in long run. In other word, the returns from these newly issued stocks are underperformed when compared to average market return or comparable stocks. This empirical result may contradict with many investors' opinion. Furthermore, the new puzzle arise why the newly issued stocks, which can generate above-average return and over performed in short run, become underperformed in long run, and many researchers try to study and explain this phenomenon.

In conclusion, there are several reasons why the long-run performance of newly issued stocks is of interest to corporations and investors;

1. If the long-run performance of newly issued stocks is relatively higher or lower than that of the matched firms, then the opportunities for active trading strategies arise. 
2. If the newly issued stocks are over or underperformed, then this evidence will raise question about the Efficient Market Hypothesis (EMH).

3. The cost of external equity capital depends on the investors' required rate of return. So if the newly issued stocks are expected to provide low return, it implies that the cost of external equity capital for the issuing firm is lower.

This study is objected to address this phenomenon in the Stock Exchange of Thailand. The methodology that has been employed in this study will partly be replicated from the study of Loughran and Ritter (1995) in order to compare the performance of newly issued stocks in Thailand with the comparable matching stocks.

The outline of this paper is as followings; Section 2 provides newly issued stocks performance in the literatures, Section 3 reports data on new issues, Section 4 shows evidence on the long-run performance of Newly issued stocks portfolios relative to the size-matched portfolios, Section 5 presents statistical tests on the time-series of cross-sectional regressions controlling for size \& BV/MV effects, and Section 6 is the summary of findings.

\section{Previous Studies about New Issues}

Many studies have shown that newly issued stocks tended to be underpriced and that newly issued stocks can make positive return to investor. They tried to explain the reason behind this underpriced in various ways. Asymmetric information arises from the fact that IPO firms were new to the market and it was relatively difficult for potential investors to find information about them. Therefore, investors' perception of higher risk for these newly issued stocks has led to the underpricing. Rock (1986) showed that the issuers need to underprice their IPO in order to attract the uninformed investors to participate in such offerings. Ellul and Pagaon (2006) proposed that this asymmetric information of IPO firms could lead to illiquidity problem. Therefore, IPO needs to be underpriced to compensate for this liquidity risk.

Brennan and Franks (1997) proposed that the newly issued stocks are underpriced because of their reduced monitoring hypothesis. Firm managements have an incentive to underprice their new issued shares because they would like to expand the distribution of the stock to a large number of small individual investors. This is to avoid the stock acquisition by the large investors like institutional investors which have more power and ability to monitor the firm's operations and decisions.

However, the underpricing and ability to make profit from purchasing them is doubtful because there are many researches showing the adverse return in the long-term. Purnanandam and Swaminathan (2004) have shown that newly issued stocks are overpriced significantly when they are compared with their industry peers. These stocks may be able to provide investors the positive initial return but they will lead to the long run poor performance. Loughran, Ritter, and Rydqvist (1994) claim that the overpriced came from the fact that the investors may be overoptimistic about the IPO stocks. Therefore, this creates the opportunity for the issuers to raise the fund easily. They call this situation as the window of opportunity for issuers. Aggarwal and Rivoli (1990) argue that this underperformance of can be subject to the fads of IPO market. They showed that the investors purchasing newly issued stocks stocks and hold it for one year will face the negative return after adjusting the movement of overall stock market.

Derrien (2005) considered the impact of noise trader sentiment in order to see the effect on IPOs. The result is consistent that IPOs are overpriced but can exhibit the positive initial return. Furthermore, the demand of individual investors which can provide the large impact on IPOs price is positively correlated with the initial return of IPOs but it is negatively correlated with the long-term stock price performance of IPOs. When noise trader sentiments are favorable and the demand for IPOs is very high, the result will be IPOs overpriced. Because of this high demand, the price of IPOs may continue increasing in short run and bring profit to the investors. However, this effect will disappear and the price will reverse and lead to underperformance in long run.

Another reason of overpriced IPOs may arise from the earning management of IPOs firms in their disclosed financial information in the prospectus. Friedlan (1994) claimed that the firms tend to use the earning management on the number in their financial statement. The good looking performance in the statement can raise the initial price of IPOs. The reason behind this is that the information about IPOs firms from other sources beside prospectus is costly for investors to obtain. Therefore, investors cannot assess the quality of financial information provided in IPOs prospectus. This information asymmetric can be the incentive for the firms to do the earning management so that the stock can be issued at relatively higher price. Teoh, Welch, and Wong (1998) showed that the poor performance of IPOs is positively correlated with the size of discretionary accruals. These accruals are the proxy to measure the level of earning management. This implies that the IPOs which engage in earning management looking from larger accruals will face the long run poorer performance. 
Furthermore, the information asymmetry can raise another issue. In the model of Myers and Majluf (1984), the issuers should know more than the market about the real value of their assets, and so issuing debt is always better than issuing equity. Therefore, the firm may issue equity only if they see that the price of issuance is overpriced. Another study by Eckbo and Masulis (1995) showed that market reaction with the firm's decision to issue securities is different. The market will not react significantly when the debts or preferred stocks are issued. However, this market reaction becomes strong when the common stocks are issued. Negative market reaction is significant after the firms announce to issue new shares of common stock. This can be one of the reasons behind the poor performance of newly issued stocks. Zheng and Stangeland (2007) documented the evidence that underpricing IPO is related the growth of sales and EBITDA after IPO, but not the growth in profit. Underpricing IPO firms processed higher quality of earning because of the growth of sales and EBITDA is difficult to be manipulated compared to profit.

Ritter (1991) studied about the long run return of newly issued stocks stocks. He compared the cumulative average adjusted return on newly issued stocks to the comparable firms which are matched by the same industry and similar market capitalization. The results showed that return on newly issued stocks is underperformed when compared to their comparable matching firms for the measurement of three years after the first trading day. He also addressed this phenomenon as the result from the fact that the firms will do the IPO during their peak of the industry fads. Loughran et al. (1994) also extended the study about this underperformance of newly issued stocks stocks to other countries. Almost every country in this study showed the negative abnormal return from the measurement of three years after the first trading day. Loughran and Ritter (1995) extended the above study in US by including both IPO and the seasoned equity offerings. The results were consistent with the previous one that the returns for three years of IPO were underperformed compared to their matching stocks. Interestingly, IPO performance became worse in the longer term as they are measured for five years instead of three years.

However, some researches from Asian market showed the contradicting results. In Taiwan, Yen and Liu (1994) examined the returns from IPO and reported the significantly positive returns during the first year. Although the stock prices seemed to decline after one year, they showed the positive return after three years. Chen and Chen (2010) was the most recent study in Taiwan and the results were consistent with the previous one. They used five factors model which are three factors from Fama and French model plus the leverage and liquidity risk factors. The results showed that IPO outperformed the market during five years after the issuance. Another study from Malaysia showed that the returns from investing in IPO in Malaysia outperformed the overall market which can be measured by the significantly positive cumulative market adjusted return over three years period after the listing day (Corhay, Teo, and Rad 2007).

\section{Data on New Issues}

This paper uses the data of IPO in the Stock Exchange of Thailand (SET) for the period of $1990-2006$. The data is collected from Reuters and DataStream Database. The data starts from the year 1990 for the reason that The Stock Exchange of Thailand was found in 1975, so in order to be able to find the stable size-matched firms, the market should be operating for at least 10 years and during 1990, the number of listed companies has crossed over 120. The end year of 2006 is for the reason that the newly issued stock returns will be computed for the holding period of three years, so in order to compute the holding period returns for the IPO in the year 2006, the price series are needed from the year 2006 to the year 2009. The stock prices are adjusted for dividends and stock splits.

The data includes:

(1) Lists of the IPO during 1990 - 2006, and their first trading days;

(2) Market closed price of each newly issued stocks and its size-matched firm on

- $\quad$ the first trading day;

- $\quad$ the $3^{\text {rd }}$ year anniversary; and

- $\quad$ the $5^{\text {th }}$ year anniversary.

(3) Monthly closed price of each IPO and its size-matched firms;

(4) Monthly SET index; and

(5) Monthly Market Value and Book-to-Market Value of all listed companies in SET.

\section{Evidence on the Long-Run Performance of New Issues}

For newly issued stocks and their sized-matching firms, the holding period return was measured by 


$$
R_{i t}=\prod_{t=1}^{T}\left(1+r_{i t}\right)-1
$$

Where $\mathrm{T}$ is the $3^{\text {rd }}$ anniversary and the $5^{\text {th }}$ anniversary. The average equally weighted holding-period returns for both the firms issuing in year $t$ were measured by equation

$$
R_{i T}=\frac{1}{n} \sum_{i=1}^{n} R_{i t}
$$

Where $\mathrm{R}_{\mathrm{i}, \mathrm{T}}$ is the percentage buy-and-hold return on firm i for holding period $\mathrm{T}$.

At the time of going public, each newly issued stocks is matched with the seasoned firm (SET-listed for at least five years, having the closest, but higher market capitalization).

The wealth relatives for each cohort year is defined as the ratio of the end-of-period wealth from holding a portfolio of newly issued stocks (IPO) to the end-of-period wealth from holding a portfolio of matching firms with the same starting market capitalization. The wealth relatives are ratios of average gross returns and are not average of ratios.

The total IPO during 1990 - 2006 was 325 firms. After excluding the 11 IPO during the financial crisis, the sample consists of 314 IPO listed on the Stock Exchange of Thailand (SET). Buy-and-hold returns for the firms going public in cohort year $t$ are computed using the first trading day closing price as the purchase price. The selling price for each IPO firm is the closing price on its third (or fifth) -anniversary date. Wealth relatives are computed as

$$
W L=\frac{\sum_{i=1}^{n}\left(1+R_{i T}\right)}{\sum_{m=1}^{n}\left(1+R_{m T}\right)}
$$

where $\mathrm{R}_{\mathrm{iT}}$ is the holding-period return from the first closing price until the three-year (or five-year) anniversary of the IPO, $\mathrm{R}_{\mathrm{mT}}$ is the holding-period return on a matching firm over the same holding period, and the summations are over the N observations in a cohort year. For example, 1990's three-year wealth relative of 0.6974 is computed as $0.9294 / 1.3328$, with 0.9294 being the terminal wealth per dollar invested after having a loss of -7.06 percent on the new issue portfolio.

Table 1 reports three-year holding period of buy-and-hold returns and wealth relatives for the 325 firms going public between 1990 and 2006. The overall three-year wealth relative is 0.85 , surprisingly close to the 0.83 reported in Ritter (1991) for 1,526 IPO in the U.S. market from 1975 - 1984.

The three-year and five-year buy-and-hold return numbers in Table 1 and Table 2 can be used to measure the investment in issuing firms that is required in order to have the same wealth three years and five years later as would be produced by an investment in non-issuing firms. For example, assume that the non-IPO stock is priced at 100 Baht per share and the non-IPO has the three-year holding period return of $20 \%$, then the terminal wealth of investing in this non-IPO is $120 \mathrm{Baht}$ per share. If the IPO has three-year holding period return of $10 \%$, then in order to have the same wealth as the non-IPO investment, the beginning IPO investment need to be equal to ' $a$ ' such that $\mathrm{a}^{*} 1.1=120$ so ' $\mathrm{a}$ ' is equal to 109.09 or in another word, IPO need $9.09 \%$ higher initial investment in order to receive equal terminal wealth as the non-IPO.

The reported three-year buy-and-hold returns in Table 1 implies that, for 100 Baht initial investment, the matching-firm portfolio's terminal wealth is 108.5758 , and the IPO portfolio would need 117.63 initial investment, which is $17.63 \%$ higher than that of the non-IPO portfolio. Table 2 reports total returns and wealth relatives based on five-year holding periods. The mean wealth relative falls to 0.72 .

For the five-year buy-and-hold returns in Table 2, it can be computed in the same manner that the IPO portfolio would need to invest $38.62 \%$ more money in order to achieve the same wealth level as that of the non-IPO portfolio after the investment horizon of five years.

Table 3 reports the mean return on IPO portfolios and matching portfolios for each year since year 1 to year 5 . To construct the IPO portfolio for the first year, we buy each IPO at each of its first closing price and hold it for one year. The t-stat for difference is the t-stat based on the independent samples t-test for two independent samples. In the first year, the performance of the IPO portfolio is significantly higher than that of the matching portfolio ( $p$ $<.05)$. However, in the following years except year 3 , the IPO portfolios relatively underperform when compare to each matching portfolio, at $5 \%$ significant level.

Besides the non-IPO matching portfolio, the alternative benchmark for comparing the performance of IPO is SET index. Table 4 presents the average holding-period returns of IPO and the benchmarks. For three-year holding 
period, the new issues portfolio is underperform by $14 \%-15 \%$ relative to both the size-matched non-IPO portfolio and the market portfolio. In addition, we notice that the non-IPO portfolio performance was similar to that of the market portfolio. For five-year holding period, the performance of newly issued stocks becomes worse. The terminal value of new issues portfolio declines to only $72.14 \%$ of the terminal value of sized-matching stocks.

\section{Statistical Tests Controlling for Size \& BV/MV Effects}

The firms going public are mostly growth stocks, so they have relatively low book-to-market ratios, and they would be expected to have low returns as suggested by Fama and French (1992). As a result, we use cross-sectional multiple regression to control for both size and book-to-market effects when testing for the significance of the relationship between IPO and returns.

$$
R_{i t}=\beta_{0}+\beta_{1} \ln \left(M V_{i t}\right)+\beta_{2} \ln (B V / M V)_{i t}+\beta_{3} I P O_{i t}+\varepsilon_{i t}
$$

Where $\mathrm{R}_{\mathrm{it}}$ represents the return of stock i at month t. $\ln \mathrm{MV}_{\mathrm{it}}$ is natural logarithm of the market value of equity. $\ln$ $(\mathrm{BV} / \mathrm{MV})_{\mathrm{it}}$ is natural logarithm of the book-to-market ratio. $\mathrm{IPO}_{\mathrm{it}}$ represents dummy variable taking on the value of 1 if it is the return of new issues or IPO. The cross-sectional regression is run year-by-year based on equation 4 and the average of coefficients of those cross-sectional regressions is obtained to get the result as shown in table 5 .

Table 5 reports the result of equation 4 . All coefficients are not significant at $5 \%$ level. The regression is not surprising since the standard deviation of each variable is quite high. However, we can see that the signs of the coefficients are reasonable. In model 1 , only dummy variable representing IPO is included. The negative coefficient shows that, in average, the return on IPO stocks is lower than non-IPO. However, higher standard error reflects high variation in return on IPO stocks. In model 2, the coefficient of BM/MV is positive, which is consistent as high-value stocks (low BM/MV) can generate higher return. The coefficients of size are relatively small, implying that there is no or less size effect on the return. Moreover, the sign of size coefficient is negative, which is inconsistent with Fama and French (2002) as they show that smaller firms could generate higher return. Negative sign of size coefficient implies that larger firms tend to generate higher return. This could be the unique characteristics of emerging market or Thai market, which needs to be examined more to address this issue. In model 3 , with the presence of IPO dummy, the size effect decreases by ten times. Also the coefficient of IPO dummy in model 3 is half of that of model 1 , which could be interpreted that the positive size effect on stock returns found in model 2 is partly from the underperformance of IPO stocks.

\section{Conclusion}

The overall results show that newly issued stocks are underperforming in the long-run. Comparing the IPO portfolio with the matching-firm portfolio, the IPO portfolio has ending value of approximately $15 \%$ lower than that of the matching-firm portfolio after the holding period of three years. For five-year holding periods, the IPO portfolio also underperform by having the ending value of approximately $29 \%$ lower than that of the matching-firm portfolio. Therefore, IPO stocks are not appropriate for buy-and-hold investors, especially for longer term. Investors could earn higher return by investing in size-matched non-IPO stocks instead of IPO stocks. Another implication for underperformance of IPO stocks is for the regulator. This long-run underperformance of IPO stocks reflects the overall quality of list firms in the stock exchange.

The possible explanations to this evidence are that investors may overvalue the growth opportunity or excessive demand on the first trading day reflects 'Greed' of investors. Overvaluing growth opportunity may be the result from misperception of investors or from the accounting manipulation, which reflects the low quality of earning of IPO firms. If it is from the latter, the regulator may need to review the accounting standard and auditing control.

The research could be extended to compare the degree of IPO underpricing across different regime e.g. before, during, and after the financial crisis or to use both industry-match in substitution of size-match non-IPO. Moreover, it is interesting to investigate this long-run underperformance whether IPO price is too low or closing price of IPO stocks on the first trading day is too high.

\section{References}

Aggarwal, R., \& Rivoli, P. (1990). Fads in the Initial Public Offering Market? Financial Management, 19(winter), 45-57.

Brennan, M., \& Franks, J. (1997). Underpricing, ownership and control in initial public offerings of equity securities in the UK. Journal of Financial Economics, 45(3), 391-413. http://dx.doi.org/10.1016/S0304-405X(97)00022-6

Chen, A., \& Chen, L.-W. (2010). Leverage, liquidity and IPO long-run performance: evidence from Taiwan IPO markets. International Journal of Accounting and Information Management, 18(1), 31-38. http://dx.doi.org/10.1108/18347641011023261 
Corhay, A., Teo, S., \& Rad, A. T. (2002). The long run performance of Malaysian initial public offerings (IPO): value and growth effects. Managerial Finance, 28(2), 52-65. http://dx.doi.org/10.1108/03074350210767690

Derrien, F. (2005). IPO Pricing in 'Hot' Market Conditions: Who Leaves Money on the Table? Journal of Finance, 60(1), 487-521. http://dx.doi.org/10.1111/j.1540-6261.2005.00736.x

Eckbo, B. E., \& Masulis, R. (1995). Seasoned equity offerings: a survey. In R. A. Jarrow, W. T. Ziemba, and V. Maksimovic (Ed.), The Finance Handbook (Vol. 9, pp. 1017-1072). Amsterdam: North-Holland.

Ellul, Andrew, \& Pagano, Marco. (2006). IPO Underpricing and After-Market Liquidity. The review of Financial Studies, 19(2), 381-421. http://dx.doi.org/10.1093/rfs/hhj018

Fama, Eugene F., \& French, Kenneth, R. (1992). The Cross-Section of Expected Stock Returns. The Journal of Finance, 47(2), 427-465. http://dx.doi.org/10.2307/2329112

Friedlan, J. (1994). Accounting choices by issuers of initial public offerings. Contemporary Accounting Research, 11, 1-32. http://dx.doi.org/10.1111/j.1911-3846.1994.tb00434.x

Loughran, T., \& Ritter, J. (1995). The New Issue Puzzle. The Journal of Finance, 50(1), 23-51. http://dx.doi.org/10.1111/j.1911-3846.1994.tb00434.x

Loughran, T., Ritter, J., \& Rydqvist, K. (1994). Initial Public Offering: International Insights. Pacific-Basin Finance Journal, 2, 165-199. http://dx.doi.org/10.1016/0927-538X(94)90016-7

Myers, S. C., \& Majluf, N. (1984). Corporate financing and investment decisions when firms have information that investors do not have. Journal of Financial Economics, 13, 187-221. http://dx.doi.org/10.1016/0304-405X(84)90023-0

Purnanandam, A., \& Swaminathan, B. (2004). Are IPO really underpriced?. The Review of Financial Studies, 17(3), 811-848. http://dx.doi.org/10.1093/rfs/hhg055

Ritter, J. (1991). The long-run performance of initial public offerings. The Journal of Finance, 42, 365-394.

Rock, K. (1986). Why new issues are underpriced. Journal of Financial Economics, 15, 187-212. http://dx.doi.org/10.1016/0304-405X(86)90054-1

Teoh, S., Welch, I., \& Wong, T. J. (1998). Earnings management and the long-run performance of initial public offerings. Journal of Finance, 53, 1935-1974. http://dx.doi.org/10.1111/0022-1082.00079

Yen, G., \& Liu, N. (1994). On the stock performance of initial public offerings: short-run or long-run phenomenon?. Paper presented at the 1994 Annual Meeting of Chinese Finance Association.

Zheng, Steven X., \& Stangeland, David A. (2007). IPO Underpricing, Firm Quality, and Analyst Forecasts, Financial Management, 36(2), 45-64. http://dx.doi.org/10.1111/j.1755-053X.2007.tb00086.x

Table 1. Mean Buy-and-Hold Returns (\%) of IPO Portfolios and Matching Portfolios for the Three-Year Holding Period.

\begin{tabular}{ccccc}
\hline & & \multicolumn{3}{c}{ Mean Buy-and-Hold Returns (\%) 3 yrs } \\
\cline { 3 - 5 } Cohort Year & \# IPO & IPO & Matching & Wealth Relative \\
\hline $\mathbf{1 9 9 0}$ & 21 & -7.0561 & 33.2789 & 0.6974 \\
$\mathbf{1 9 9 1}$ & 35 & 60.4553 & 79.1021 & 0.8112 \\
$\mathbf{1 9 9 2}$ & 23 & -20.5774 & 59.4769 & 0.7053 \\
$\mathbf{1 9 9 3}$ & 26 & 10.8556 & -20.3905 & 0.8045 \\
$\mathbf{1 9 9 4}$ & 34 & -59.3371 & -55.7904 & 0.8131 \\
$\mathbf{1 9 9 5}$ & 20 & -49.5682 & -74.8457 & 0.8614 \\
$\mathbf{1 9 9 6}$ & 23 & -66.8673 & -54.9896 & 0.8529 \\
$\mathbf{1 9 9 7}$ & 4 & -40.6431 & -67.2764 & 0.8979 \\
$\mathbf{1 9 9 8}$ & 1 & & & \\
$\mathbf{1 9 9 9}$ & 0 & & & \\
$\mathbf{2 0 0 0}$ & 2 & & & 0.8485 \\
$\mathbf{2 0 0 1}$ & 8 & & 173.2998 & 0.8136 \\
$\mathbf{2 0 0 2}$ & 19 & 97.3454 & 11.7290 & 0.8408 \\
$\mathbf{2 0 0 3}$ & 21 & -42.9822 & -6.8370 & 0.8469 \\
$\mathbf{2 0 0 4}$ & 34 & 7.8481 & 6.0900 & 0.8414 \\
$\mathbf{2 0 0 5}$ & 39 & -3.0344 & -7.6317 & $\mathbf{0 . 8 5 0 1}$ \\
$\mathbf{2 0 0 6}$ & 15 & -29.2947 & $\mathbf{8 . 5 7 5 8}$ & \\
\hline
\end{tabular}


Table 2. Mean Buy-and-Hold Returns (\%) of IPO Portfolios and Matching Portfolios for the Five-Year Holding Period.

\begin{tabular}{ccccc}
\hline & & \multicolumn{3}{c}{ Mean Buy-and-Hold Returns (\%) 5 yrs } \\
\cline { 3 - 5 } Cohort Year & \# IPO & IPO & Matching & Wealth Relative \\
\hline $\mathbf{1 9 9 0}$ & 21 & -8.5363 & 22.8197 & 0.7447 \\
$\mathbf{1 9 9 1}$ & 35 & 13.0332 & 67.6817 & 0.7039 \\
$\mathbf{1 9 9 2}$ & 23 & -56.9323 & -3.3650 & 0.6395 \\
$\mathbf{1 9 9 3}$ & 26 & -19.9139 & -60.6698 & 0.7683 \\
$\mathbf{1 9 9 4}$ & 34 & -66.9854 & -72.1079 & 0.7938 \\
$\mathbf{1 9 9 5}$ & 20 & -52.3246 & -59.9033 & 0.8258 \\
$\mathbf{1 9 9 6}$ & 23 & -69.5439 & -49.1661 & 0.8047 \\
$\mathbf{1 9 9 7}$ & 4 & 118.0892 & -62.5513 & 1.1272 \\
$\mathbf{1 9 9 8}$ & 1 & & & \\
$\mathbf{1 9 9 9}$ & 0 & & & \\
$\mathbf{2 0 0 0}$ & 2 & & & \\
$\mathbf{2 0 0 1}$ & 8 & & 321.5439 & 0.8356 \\
$\mathbf{2 0 0 2}$ & 19 & 82.3387 & -2.4309 & 0.8098 \\
$\mathbf{2 0 0 3}$ & 21 & -46.9172 & -19.2976 & 0.8188 \\
$\mathbf{2 0 0 4}$ & 34 & -24.0457 & $\mathbf{5 . 4 0 7 7}$ & $\mathbf{0 . 7 2 1 4}$ \\
\hline
\end{tabular}

Table 3. Mean Return (\%) for Each Year of IPO Portfolio and Their Size-Matched Non-IPO Portfolio

\begin{tabular}{cccccc}
\hline Period & $\begin{array}{c}\text { Mean IPO } \\
\mathbf{( \% )}\end{array}$ & Mean non-IPO(\%) & $\begin{array}{c}\text { t-stat } \\
\text { for difference }\end{array}$ & Sample size \\
\hline $\mathbf{1}^{\text {st }}$ Year & 7.5514 & 3.7108 & $11.6052^{* *}$ & 311 \\
$\mathbf{2}^{\text {nd }}$ Year & -3.5275 & 1.6421 & $-13.05^{* *}$ & 311 \\
$\mathbf{3}^{\text {rd }}$ Year & 3.6173 & 2.9941 & 1.2001 & 311 \\
$\mathbf{4}^{\text {th }}$ Year & -6.3979 & 2.7355 & $-17.066^{* *}$ & 301 \\
$\mathbf{5}^{\text {th }}$ Year & 8.3223 & 14.7594 & $-13.344^{* *}$ & 272 \\
\hline
\end{tabular}

$* *$ indicate significant at $5 \%$

Table 4. The Relative Performance of New Issues Compared to Alternative Benchmarks

\begin{tabular}{lcccc}
\hline & \multicolumn{2}{c}{ Average 3 years } & \multicolumn{2}{c}{ Average 5 years } \\
\cline { 2 - 5 } & Return (\%) & $\begin{array}{c}\text { Wealth } \\
\text { Relative }\end{array}$ & Return (\%) & $\begin{array}{c}\text { Wealth } \\
\text { Relative }\end{array}$ \\
\hline New Issues (IPO) & -7.6973 & 1.0000 & -23.9580 & 1.0000 \\
Size-matched & 8.5758 & 0.8501 & 5.4077 & 0.7214 \\
SET index & 10.425 & 0.8359 & -8.5789 & 0.8318 \\
\hline
\end{tabular}

Table 5. Average coefficients for five-year holding period returns (Number in parenthesis is t-stat)

\begin{tabular}{cccc}
\hline Coefficient & Model 1 & Model 2 & Model 3 \\
\hline Size & & 0.0200 & 0.0024 \\
& & $(0.13)$ & $(0.173)$ \\
Book-to-Market & & 0.4665 & 0.3758 \\
& & $(0.991)$ & $(0.939)$ \\
IPO Dummy & -0.4606 & & -0.271 \\
& $(-0.535)$ & & $(-0.004)$ \\
\hline
\end{tabular}

